\title{
Grammatical Errors Made By Students' on the Technique of Making Idiomatic Translation in the Politic Texts
}

\author{
Siska Widya \\ English Teacher, SMP Swasta Al Maksum, Medan \\ Email: siskawidya111985@gmail.com
}

\begin{abstract}
English is an important role in education or technology since it functions as one of the international languages. The aim is to describe a type of grammatical error and find out the causes of errors in translating vocative text based on the idiomatic translation. The research was conducted at SMP Swasta Al-Maksum. The research design used descriptive quantitative. The population of this research was students consist of 41 students. The technique sampling was purposive sampling, sample is 41 students. The test was teacher-made. The data were acquired by administrating an objective test was a text which consisted of 10 items to test their knowledge in translating the text based on idiomatic translation, each correct translation has scores one and the incorrect translation was scored zero. The findings showed that $71 \%$ of samples were able and $29 \%$ of samples were unable in translating the text based on idiomatic translation. It means that students were able to translate the textbased on idiomatic translation.
\end{abstract}

Keyword: grammatical, error, technique, idiomatic, translation 


\section{CHAPTER I INTRODUCTION}

One of the languages in the world is English. It has an important role in education or technology since it functions as one of the international languages. Language is essential for human beings. A language is seen as a phenomena observable and even process of automaticity. It focuses on the relationship of stimuliresponses by strengthening that relationship through more exercises/practices (Aprianto \& Zaini, 2019). In studying English, we have four basic skills of language that every student must learn. They are reading, writing, speaking, and listening.

Though some researchers claim that politeness expressions were translated in a certain lexicon without context, the fact that politeness expressions should be translated in a context or in a pragmatic way (Roni, 2020). The translation is to change a form. According to Larson (1998) translation is classified into two main types, namely form-based and meaning-based translation. Form-based translation attempts to follow the form of the Source Language and is known as literal translation, while meaning-based translation makes every effort to communicate the meaning of the SL text in the natural forms of the receptor language.

Nuraini (2019) found 178 errors in fourteen linguistic categories which are divided into four parts: omission, addition, misformation, and misordering. From all the four parts, the researcher discovered that the most frequent errors found are in the part of misformation. Some students may have difficulties in translating. The students translate sentences incorrectly, and the others here translate them idiomatically. Utami (2017) state that the most frequent error made by the students was local errors and the fewest error made by the students was other errors.

According Wulandari and Harida (2021) state that by writing English sentences according to the grammatical structure, the meaning of it will be accurate, easily understood and acceptable. The findings Tse (2014) also showed that the English writing skill of the secondary male students in schools needs more reinforcement and development (Chua, Lim, Soon, Tang, \& Ranaivo-Malançon, 2017). 
For the above reason, the researcher will analyze grammatical errors in translate idiomatic translation in vocative text. The reasons for choosing this title of the thesis are: 1) translation is important of English subject for students, in which by understanding the translation, the students may understand the English text easily, 2) most students still grammatical errors in translating the text based on the idiomatic translation, 3) students still do not know whether the words they would translate should be translated literally or idiomatically.

In this research, the researcher realizes that the mistakes and errors made by students in translating vocative text based on idiomatic translation. The students did not realize that they have made errors having they realized the problem. I am interested in studying the grammatical errors in translating idiomatic translation in vocative text. The aim is to describe a type of grammatical error and find out the causes of errors in translating vocative text based on the idiomatic translation. 


\section{CHAPTER II \\ METHODE OF RESEARCH}

\section{Research Design}

The research design used descriptive quantitative. Data in this research is static or quantitative data based on the students' achievement in translating idiomatic translation in vocative text.

\section{Location}

The research was conducted at SMP Swasta Al-Maksum, Desa Cinta Rakyat, Kecamatan Percut Sei Tuan, Kabupaten Deli Serdang.

\section{Population and Sample}

The population of this research was the students of SMP Swasta Al-Maksum. The total number of students was 272 . The sample gets $15 \%$ for each class of 41 students, sampling techniques using purposive sampling. The criteria inclusion include students who are able to communicate well, cooperatively, have good grades in English lessons. Arikunto (2013) suggested that $10-15 \%$ or $20-25 \%$ or more as a sample when the population is more than 100 is enough. The following table is the population and sample data.

\section{The Instrument for Collecting the Data}

In this research, a set of translation tests to the students. The test consisted of vocative text, and the students have asked to translate the text into Indonesian based on idiomatic translation. In translating vocative text, grammatical aspects evaluated compound-complex sentences, compound nouns, collective nouns, noun phrases, and adverb clauses of condition. Translate of vocative text needed time about 60 minutes.

\section{The technique of Analysis Data}

The data of analysis was to identify the cause of the problems. In analyzing the student's errors, the research will use some procedures, they were: 1) identifying the students' errors, 2) classifying the errors, 3) deriving the dominant errors, and 4) finding solution of the errors. 


\section{CHAPTER IV}

\section{DATA ANALYSIS, FINDINGS, AND DISCUSSIONS}

\section{Data Analysis}

The data analysis was basically to answer the formulation of the problems, state this research is to find out whether the students' errors in translating the textbased idiomatic translation. The students' error in translating English text into the Indonesian language by using idiomatic translation procedures then the calculation is consulted to the criteria of the ability.

The following Table I is the analysis of samples errors in translating the test:

Table I

The Analysis Sample

\begin{tabular}{ccccc}
\hline No. & Correct & \% & Error & \% \\
\hline 1. & 24 & 58,54 & 17 & 41,46 \\
2. & 36 & 87,80 & 5 & 12,20 \\
3. & 31 & 75,61 & 10 & 24,39 \\
4. & 29 & 70,73 & 12 & 29,27 \\
5. & 25 & 60,98 & 16 & 39,02 \\
6. & 27 & 65,85 & 14 & 34,15 \\
7. & 39 & 95,12 & 2 & 4,88 \\
8. & 24 & 58,54 & 17 & 41,48 \\
9. & 36 & 87,80 & 5 & 12,20 \\
10. & 20 & 48,78 & 21 & 51,22 \\
\hline Total & 291 & 71,00 & 119 & 29,00 \\
\hline
\end{tabular}

Based on Table I show that $71 \%$ of their items can be translated correctly. and $29 \%$ of items are unable to translate. The following analysis is the analysis they translate to find out their error and their causes: 1) $58,54 \%$ of the students translate into item number I, and $41,46 \%$ were unable to translate sentences, 2) $87,80 \%$ of the students translate item number II, and $12,20 \%$ were unable to translate sentences, 3) $75,61 \%$ of the students translate item number III, and $24,39 \%$ were unable to translate sentence, 4) $70,73 \%$ of the students translate item number IV, and 29,27\% were unable to translate sentences, 5) $60,98 \%$ of the students who translate item number V, 
and $39,02 \%$ were unable to translate sentences, 6) $65,85 \%$ of the students translate item number VI, and $34,15 \%$ were unable to translate sentences, 7) $95,12 \%$ of the students translate item number VII, and $4,88 \%$ were unable to translate sentences based, 8) 58,54\% of the students translate item number VIII, and 41,48\% were unable to translate sentences, 9) $87,80 \%$ of the students translate item number IX, and $12,20 \%$ were unable to translate sentences, 10) $48,78 \%$ of students who translate item number $\mathrm{X}$, and $51,22 \%$ were unable to translate sentences based on the idiomatic translation.

\section{Findings}

The following Table II is the finding of study:

Table II

The Students' Ability in Translation

\begin{tabular}{clccc}
\hline No. & & Ability Status & $\begin{array}{c}\text { Frequency } \\
(\boldsymbol{f})\end{array}$ & $\begin{array}{c}\text { Percentage } \\
(\boldsymbol{\%})\end{array}$ \\
\hline 1 & Poor & 2 & 4,88 \\
2 & Good & 8 & 19,51 \\
3 & Very Good & 24 & 58,54 \\
4 & Excellent & & 7 & 17,07 \\
\hline \multicolumn{2}{r}{} & Total & $\mathbf{4 1}$ & $\mathbf{1 0 0}$ \\
\hline
\end{tabular}

There are seven students got the status of Excellent (17,07\%). There are 24 students $(58,54 \%)$ are very good, and eight students $(19,51 \%)$ are good, and two students $(4,88 \%)$ are Poor. There are 39 students $(95,12 \%)$ who were able to translate English text into Indonesian correctly by using idiomatic translation procedures. two students $(4,88 \%)$ were unable.

\section{Discussions}

The resulted of this study are $71 \%$ of samples were able to translate the textbased on idiomatic translation, and $29 \%$ of samples were unable to translate the textbased on idiomatic translation. Most of the students still face difficulties in practicing English, especially in grammar. The students sometimes make mistakes in translating 
an idiomatic translation. They did not know how the way to translate the text based on the idiomatic translation well English to Indonesian.

According Dwi, Ummi Khaerati, Anugrawati, Sangkala, and Abdul (2018) showed that the students make error in Indonesian to English translation text, it found the kinds of error and the sources of error that made by students in translating a text Indonesian into English. The kinds of error were inversion of meaning students, omission of meaning made by students, addition of meaning, and deviation of meaning. Utami (2017) showed that the types of grammatical errors made by the students in their translation were three types, namely global errors, local errors, and other errors.

Findings Al-Amri (2020) indicated that participants showed a high level of perceived knowledge, knowledge on written tests, expressed positive attitudes towards the learning approach, and performed better in the post-videotaped evaluation. According Madkour (2016) focus on five issues: the linguistics levels of literary translation, the characteristics of literary texts, the problems of translating literary texts, the main principles of the cognitive, and the relationship between literary translation theories, cognition, and creativity.

Based on the error category, students' most common error is omission, followed by overgeneralization, over-regulation, and misordering, completed by other errors such as carelessness. Meanwhile, the causes of grammatical errors were the internal factors; anxiety, limited linguistic resources, and motivation deficiency; the external factors were an unsupportive environment and the stressful teaching and learning process (Damaiyanti, 2021). The research findings reveal that the most frequent errors in both levels are errors in verbs; and that most of the errors are due to overgeneralization and the ignorance of the rule restriction (Tandikombong \& Atmowardoyo, 2016). The results Erlangga, Suarnajaya, and Juniarta (2019) showed that there were five types of errors found in students' descriptive writing, namely: omission, addition, misformation, misordering, and spelling . 


\section{CHAPTER IV CONCLUSIONS AND SUGGESTIONS}

\section{Conclusions}

1. Error analysis is a study to analyze the students' error in using the target language.

2. There are $71 \%$ of samples were able to translate the text-based on idiomatic translation. and $29 \%$ of samples were unable to translate the text-based on idiomatic translation.

3. Most of the students can translate the text-based on idiomatic translation correctly.

\section{Suggestion}

Based on the conclusion above the following is a suggestion of this study:

1. English teachers suggest using grammatical errors to find out their student's problems in learning the target language.

2. English teachers should motivate the students to study English

3. English teachers should teach grammar comprehensively.

4. Students should add their knowledge about English so that they will be able to improve their errors.

5. Students suggest learning the term grammatical. especially in translating the text based on idiomatic translation. 


\section{REFERENCES}

Al-Amri, M. N. (2020). Principles of language teaching and learning for expanding and improving classroom input strategies. Per Linguam, 36(1). https://doi.org/10.5785/36-1-794

Aprianto, D., \& Zaini, N. (2019). The principles of language learning and teaching in communication skill developments. VELES Voices of English Language Education Society, 3(1). https://doi.org/10.29408/veles.v3i1.1281

Arikunto, S. (2013). Prosedur penelitian: Suatu pendekatan praktik. Jakarta: Rineka Cipta.

Chua, C. C., Lim, T. Y., Soon, L. K., Tang, E. K., \& Ranaivo-Malançon, B. (2017). Meaning preservation in example-based machine translation with structural $\begin{array}{lllll}\text { semantics. } & \text { Expert Systems with Applications, } 78 .\end{array}$ https://doi.org/10.1016/j.eswa.2017.02.021

Damaiyanti, S. (2021). Grammatical errors made by students in speaking English. JETLe (Journal of English Language Teaching and Learning), 2(2). https://doi.org/10.18860/jetle.v2i2.11945

Dwi, R. A., Ummi Khaerati, S., Anugrawati, N., Sangkala, I., \& Abdul, B. N. (2018). Errors in Indonesian to English translation text made by students of SMA Negeri 13 Pangkep. In Jurnal Keguruan dan Ilmu Pendidikan (JKIP) FKIP Unismuh Makassar (Vol. 5).

Erlangga, I. P. B., Suarnajaya, I. W., \& Juniarta, P. A. K. (2019). An analysis of grammatical errors made by the seventh grade students of SMP Negeri 2 Sukawati in writing descriptive texts in the academic year 2018/2019. Language and Education Journal Undiksha, 2(1). https://doi.org/10.23887/leju.v2i1.20276

Larson, M. (1998). Meaning-based translation. University Press of America, 2(12).

Madkour, M. (2016). Linguistic levels of translation: A generic exploration of translation difficulties in literary textual corpus. International Journal of Applied Linguistics and English Literature, 5(6). https://doi.org/10.7575/aiac.ijalel.v.5n.6p.99

Nuraini. (2019). Grammatical errors made by the students of English Department UISU Year 2018 in Their Writing Class. KnE Social Sciences. https://doi.org/10.18502/kss.v3i19.4884

Roni, R. (2020). Pragmatic discourse of pagaralamnese imperatıve politeness and its English meanıng based translation. The International Journal of Social Sciences and Humanities Invention, 7(10). https://doi.org/10.18535/ijsshi/v7i010.03

Tandikombong, M., \& Atmowardoyo, H. (2016). Grammatical errors in the English translation made by the students of English study program of UKI Toraja. ELT Worldwide: Journal of English Language Teaching, 3(1). https://doi.org/10.26858/eltww.v3i1.1875

Tse, A. Y. H. (2014). A case study of grammatical errors made by Malaysian students. International Journal of Science Commerce and Humanities, 2(5).

Utami, S. (2017). The source of errors in Indonesian-English translation. Jurnal KATA, l(2). https://doi.org/10.22216/jk.v1i2.2351

Wulandari, R. S., \& Harida, R. (2021). Grammatical error analysis in essay writing. DEIKSIS, 13(1). https://doi.org/10.30998/deiksis.v13i1.5356 